\title{
The occurrence of epibionts of Gordiida (Nematomorpha) in Catamarca, Argentina
}

\author{
Cristina De Villalobos ${ }^{1.2 *}$, Liliana Salas ${ }^{3}$, Fernanda Zanca ${ }^{1,4}$ and Adrián Atencio ${ }^{1,4}$ \\ ${ }^{1}$ Facultad de Ciencias Naturales y Museo, Universidad Nacional de La Plata, Paseo del Bosque S/N 1900, Argentina; \\ ${ }^{2}$ Comisión de Investigaciones Científicas de la Provincia de Buenos Aires 526 entre 10 y 11 1900, La Plata, Argentina; \\ ${ }^{3}$ Facultad de Ciencias Exactas y Naturales, Avenida Belgrano 300 CP 4700, San Fernando del Valle de Catamarca, UNCa; \\ ${ }^{4}$ Consejo Nacional de Investigaciones Científicas y Tecnológicas, Avenida Rivadavia 1917, Ciudad de Buenos Aires, Argentina
}

\begin{abstract}
The presence of larvae and pupae of the genus Metrichia (Trichoptera, Hydroptilidae), larvae of the genus Macrelmis and Phanocerus (Coleoptera, Elmidae), three diatom genera Achnanthes, Cocconeis, Gomphonema, and some specimens of very small diatoms that could not be determined to species or genus level, were recorded for the first time as epibionts for Chordodes brasiliensis (Gordiida, Nematomorpha). Such epibionts were found on the body surface of this species of hairworms, captured from El Tala stream, Catamarca, Argentina.
\end{abstract}

\section{Keywords}

Gordiida, epibionts, diatoms, Trichoptera, Elmidae

\section{Introduction}

Gordiida, known as hairworms are worm-like organisms freeliving in freshwater environments as adults where they copulate and lay their eggs. Their minute larvae are obligate parasites from arthropods.

Although many gordiids have been studied for their taxonomic position and life cycle (Schmidt-Rhaesa 2002, Hanelt and Janovy 2004, De Villalobos et al. 2005, Schmidt-Rhaesa et al. 2005, Zanca et al. 2007) nothing is known about their interactions with their epibionts.

Epibiosis is a widespread relationship in aquatic environments that includes two organisms: the epibiont and the basibiont (Wahl and Mark 1999). While epibiont includes organisms that are attached to the surface of a living substratum, the basibiont lodges and constitutes a support for the epibiont (Threlkeld et al. 1993). During our investigations of gordiids, it was noted that they are basibionts for several epibionts that inhabit their body surfaces. Gordiids are mobile, providing constant flow of water and nutrients across the cuticle and thereby supplying an optimal habitat for epibionts.

Although after years of collecting different species of gordiids, the presence of epibionts on their body surfaces had been already detected in our studies, in a recent collection the abundant occurrence of epibionts on Chordodes brasiliensis has been most unusual.
Consequently, the aim of this study was to analyze the occurrence, for the first time, of the epibiont communities associated with gordiids of the species Chordodes brasiliensis collected from Catamarca, Argentina.

\section{Materials and methods}

The study was carried out in October 2008. Ninety-eight male specimens of Chordodes brasiliensis were collected from El Tala River $\left(28^{\circ} 27^{\prime} \mathrm{S}, 65^{\circ} 50^{\prime} \mathrm{W}\right)$. El Tala River belongs to the Central region, originating in the mountain range of the Ambato, Catamarca province, Argentina.

The sampling area covered $500 \mathrm{~m}$ along the stream from bank to bank (7-9 m wide). Horsehair worms were detected by visual inspection and collected by hand. Gordiids were maintained alive and placed in individual $300 \mathrm{ml}$ plastic containers with stream water.

As soon as possible in the lab, the distribution of each species of macroepibionts over the body, as well as the occurrence, were recorded and photographed under stereomicroscope for each gordiids studied. In order to examine macroepibionts in detail, $C$. brasiliensis surface was scraped with a scalpel. The extracted material was analyzed in vivo using bright field and light microscopy. Also one pupa of $\mathrm{Me}$ trichia spp. was photographed under SEM. Prevalence and mean intensity were calculated according to (Begon et al. 
1996). Coleoptera and Trichoptera were identified according to Manzo (2007) and Trémouilles et al. (1995).

Among these epibionts, three unidentified species belonging to three genera of diatoms and some specimens of very small diatoms (less than $10 \mu \mathrm{m}$ ) that could not be determined were observed by SEM on seven specimens of $C$. brasiliensis.

For scanning electron microscopy (SEM) of the diatoms, fragments of the central region of the body of $C$. brasiliensis (about $5 \mathrm{~mm}$ in length) were fixed in 95\% ethanol and dehydrated in $100 \%$ ethanol for $30 \mathrm{~min}$. Afterwards, they were critical-point dried, mounted on aluminium specimen stubs with standard adhesive pads and coated with gold-palladium. Pictures were taken on a JEOL JSM 6360 LV Scanning Electron Microscope. Based on counts of diatoms in SEM photographs we could quantify their density analyzing three randomly selected areas of each sample of $100 \mu \mathrm{m}$ high and $150 \mu \mathrm{m}$ wide for each individual studied. Also we calculated the relative frequency (RF) of each genus of diatoms.

Diatoms were identified according to Round (1990), Kramer and Lange Bertalot (1986a, b).

After completion of the afore mentioned studies the gordiids specimens as well as their epibionts were fixed in alcohol $70 \%$ and were deposited in the Invertebrate Collection of Natural Science Museum of the University of La Plata (Argentina) under the accession numbers MLP 6066 (Chordodes brasiliensis) and MLP 6066a (epibionts).

\section{Results}

During the observation of the 98 specimens of horsehairs collected $54(52.92 \%)$ show epibionts on their surface. One genus of Trichoptera, Hydroptilidae (Metrichia spp.), two genera of Coleoptera, Elmidae (Phanocerus spp. and Macrelmis spp.) (Table I) and three genera of diatoms (Achnanthes spp., Cocconeis spp. and Gomphonema spp.) (Fig. 3A, B), were identified as epibionts (Table II, III).

\section{Metrichia Ross, 1938 (Trichoptera, Hydroptilidae)}

Pupae ( $\mathbf{n}=100)$ : Caddisfly pupae of Metrichia spp. was the most widespread genera of macroepibionts $(47.6 \%)$. These epibionts, located along the entire body showed a decrease towards the posterior end on the surface of 53 specimens of C. brasiliensis (Figs $1 \mathrm{~A}, \mathrm{C}$ and $2 \mathrm{~A}, \mathrm{~B}$ ). Only one caddisfly larva of Metrichia spp. $(0.47 \%)$ was observed on the midbody of C. brasiliensis (Fig. 1B; Table I).

\section{Macrelmis Motschulsky, 1859 (Coleoptera, Elmidae)}

Sixty-eight specimens of Macrelmis spp. larvae (32.38\%) colonized the entire body surface, but were most numerous on the anterior body part of forty-six specimens of C. brasiliensis (Figs 1A, C; Table I).
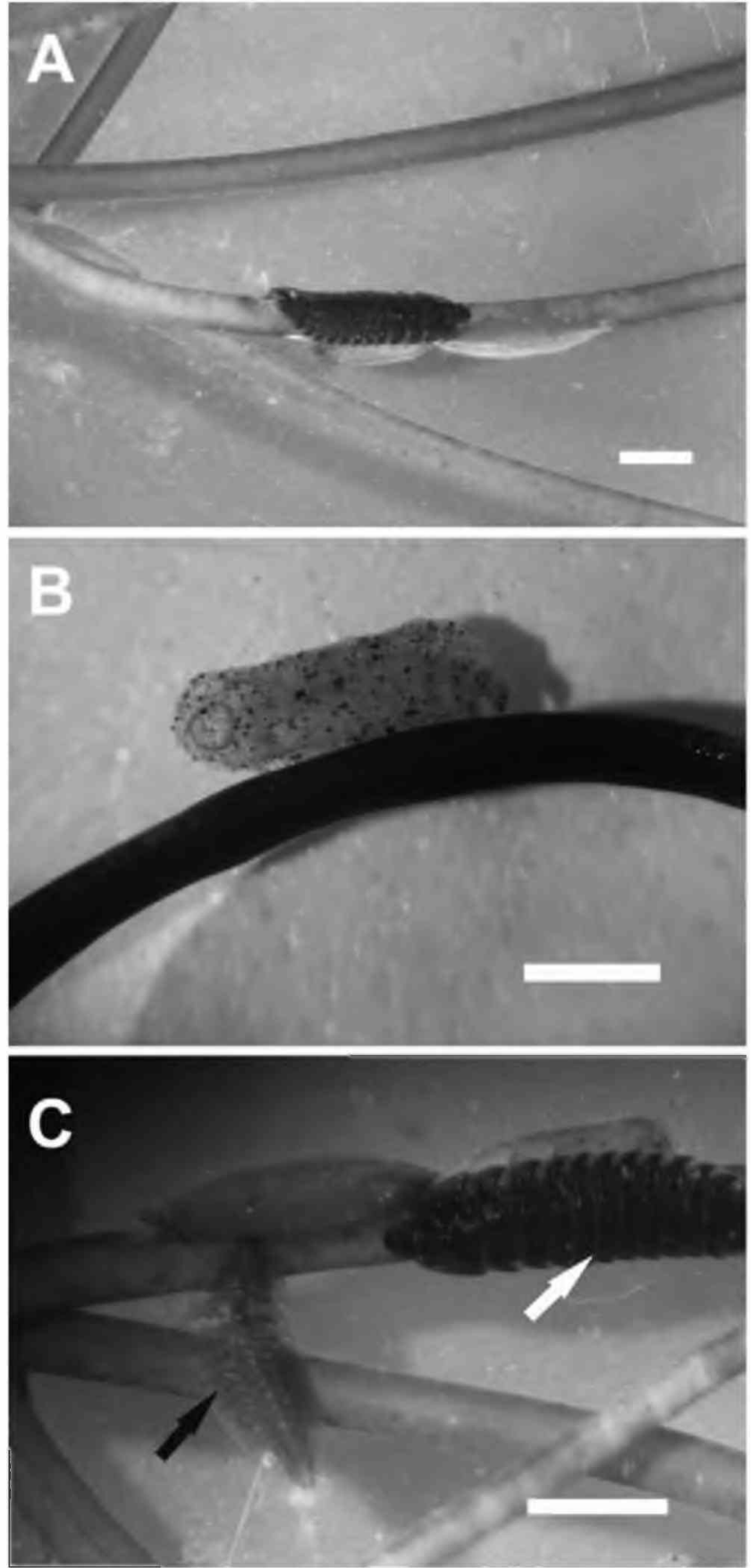

Fig. 1. Stereomicroscope. A. Two pupae of Metrichia spp. and one larva of Macrelmis on the body surface of Chordodes brasiliensis. B. Larva of Metrichia within a larval case. C. One larva of Phanocerus (black arrow), larva of Macrelmis (white arrow) and pupa of Metrichia on the body surface of C. brasiliensis. Scale bars $2 \mathrm{~mm}(\mathrm{~A}), 1 \mathrm{~mm}(\mathrm{~B}), 2 \mathrm{~mm}$ (C)

\section{Phanocerus Sharp, 1882 (Coleoptera, Elmidae)}

Forty one riffle beetles larvae $(19.52 \%)$ were found on the midbody surface of 37 specimens of C. brasiliensis (Fig. 1C; Table I) 
Table I. Prevalence and intensity of macroepibionts of Chordodes brasiliensis

\begin{tabular}{lccc}
\hline & Prevalence (\%) & \multicolumn{2}{c}{ Intensity } \\
& & range & mean \\
\hline Metrichia spp. pupae & 54.08 & $0-9$ & 1.04 \\
Phanocerus spp. larvae & 37.75 & $0-2$ & 0.43 \\
Macrelmis spp. larvae & 46.93 & $0-2$ & 0.47 \\
Metrichia spp. larvae & 1.02 & $0-1$ & 0.01 \\
\hline
\end{tabular}

\section{Diatoms}

All the specimens of $C$. brasiliensis examined by SEM $(n=7)$ presented diatoms on the cuticle (Figs 3A, B). Diatoms interact with the substratum by releasing adhesive exopolymers (mucilage) through a distinct slit in the frustule called the raphe (Hoagland et al. 1993) (Fig. 3A).

The density variation range of total diatoms was 1288 12213 diatoms $/ \mathrm{mm}^{2}(\bar{x}=6155)$. The highest mean values of diatoms density found were Gomphonema spp. $(\bar{x}=1342$ specimens per $\left.\mathrm{mm}^{2}\right)$ and Achnanthes spp. $(x=854$ specimens per $\left.\mathrm{mm}^{2}\right)$, Cocconeis spp. $\left(x=218\right.$ specimens per $\left.\mathrm{mm}^{2}\right)$, while the density of smaller diatoms $(<10 \mu \mathrm{m})$ was $\bar{x}=3741$ individuals per $\mathrm{mm}^{2}$ (Table II). The highest relative frequency is given by the smaller diatoms $(<10 \mu \mathrm{m})(\bar{x}=51.2)$ followed by Gomphonema spp. $(x=31.0)$, Achnanthes spp. $(x=12.7)$ and Cocconeis spp. $(x=5.1)$ (Table III).
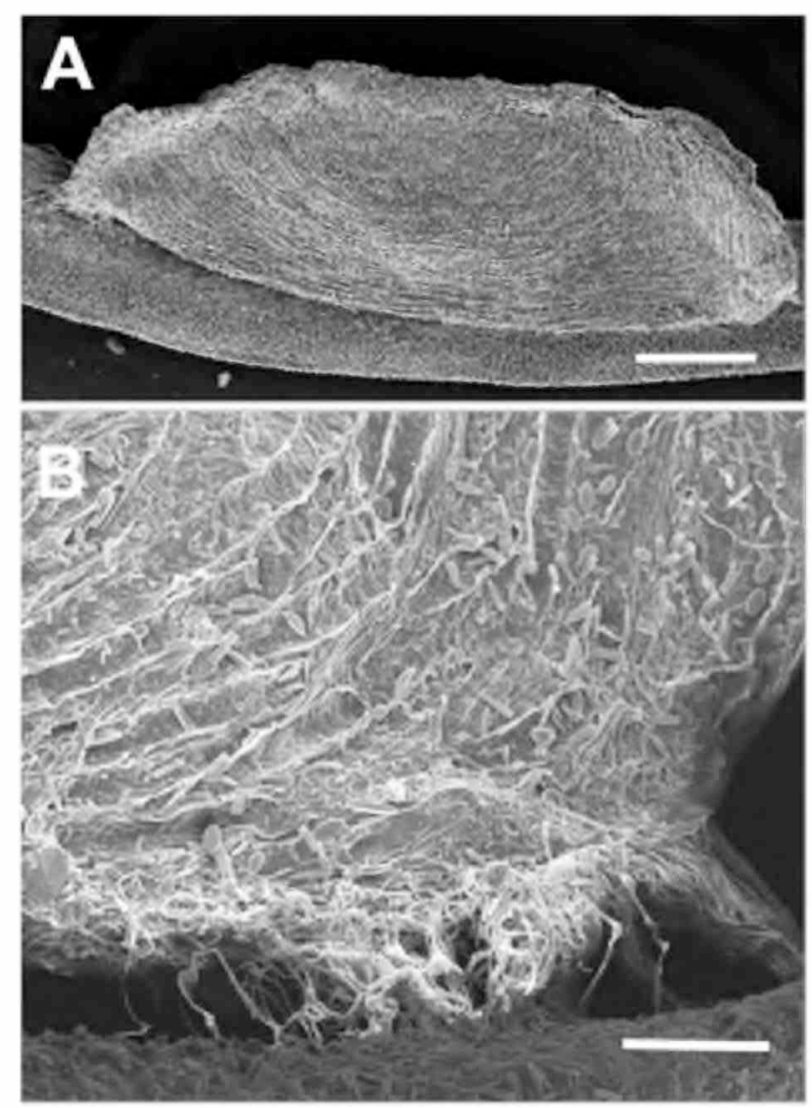

Fig. 2. SEM. A. General view of pupa of Metrichia. B. Detail of the pupa case showing silk filaments that allows the attachment to the body surface of C. brasiliensis. Scale bars $=500 \mu \mathrm{m}(\mathrm{A}), 100 \mu \mathrm{m}(\mathrm{B})$

Table II. Density of diatoms as epibionts of Chordodes brasiliensis

\begin{tabular}{ccccc}
\hline & \multicolumn{4}{c}{ Density of diatoms per mm ${ }^{2}$} \\
\cline { 2 - 5 } Samples & Gomphonema spp. & Cocconeis spp. & Achnanthes spp. & diatoms $<10 \mu \mathrm{m}$ \\
\hline 1 & 995 & 559 & 870 & 4786 \\
2 & 701 & 70 & 2103 & 6308 \\
3 & 814 & 68 & 1968 & 9363 \\
4 & 823 & 137 & 754 & 3223 \\
5 & 573 & 143 & 286 & 286 \\
6 & 3897 & 390 & 0 & 390 \\
7 & 1591 & 159 & 0 & 1829 \\
\hline Average & 1342 & 218 & 854 & 3741 \\
\hline
\end{tabular}

Table III. Relative frequency of microepibionts of Chordodes brasiliensis

\begin{tabular}{ccccc}
\hline & \multicolumn{4}{c}{ Relative frequency (\%) of diatoms } \\
\cline { 2 - 5 } Samples & Gomphonema spp. & Cocconeis spp. & Achnanthes spp. & diatoms $<10 \mu \mathrm{m}$ \\
\hline 1 & 13.8 & 7.8 & 12.1 & 66.4 \\
2 & 7.6 & 0.8 & 22.9 & 68.7 \\
3 & 6.7 & 0.6 & 16.1 & 76.7 \\
4 & 16.7 & 11.1 & 15.3 & 65.3 \\
5 & 44.4 & 2.3 & 0.2 & 22.2 \\
6 & 83.3 & 4.4 & 0.0 & 51.1 \\
7 & 44.4 & 5.1 & 12.7 & 51.2 \\
\hline Average & 31.0 & & & Download Date | 8/26/19 8:03 PM
\end{tabular}




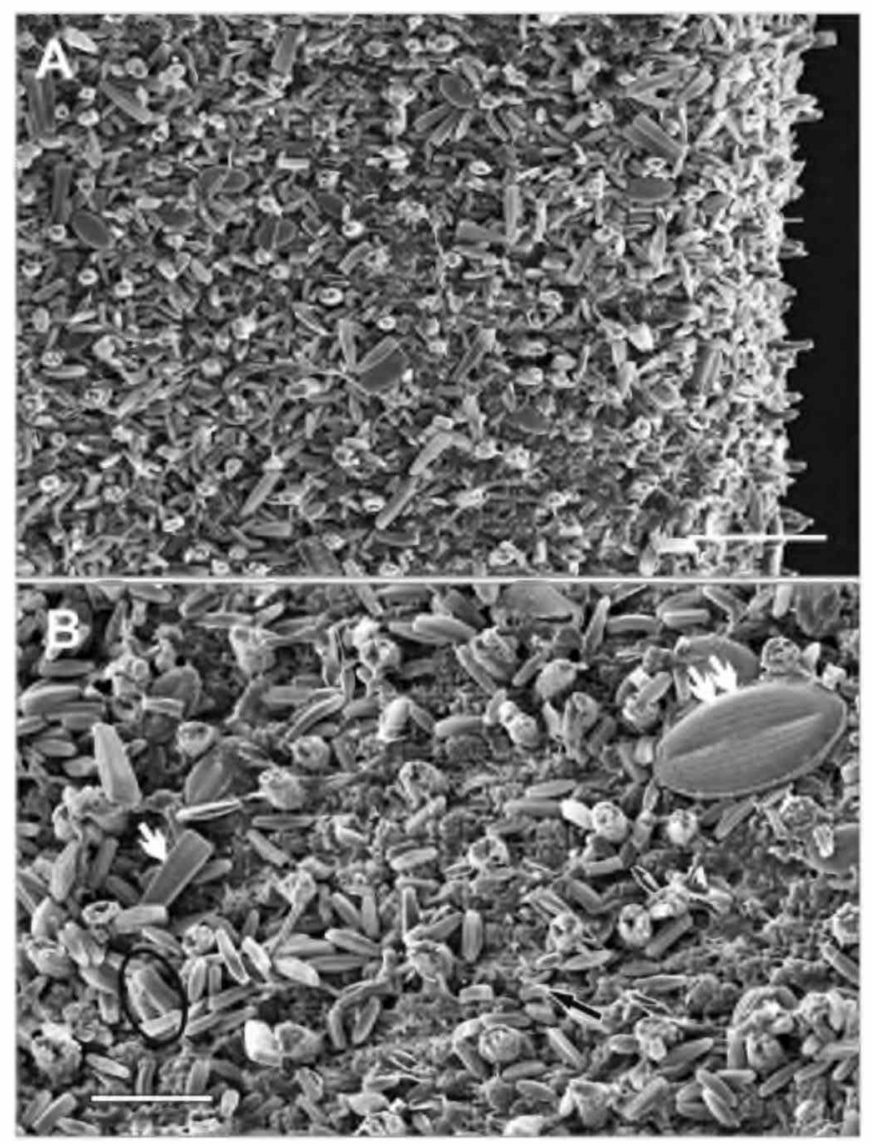

Fig. 3. SEM. A. General view of diatoms adhered to the cuticle of C. brasiliensis by a mucilage stalk. B. Three of main genera of diatoms identified upon cuticle of $C$. brasiliensis. Double white arrows show Cocconeis spp.; simple white arrow shows Gomphonema spp., black circle shows two cells of the Achnanthes spp. forming short bands and black arrow shows indeterminate diatoms $(<10 \mu \mathrm{m})$. Scale bars $=50 \mu \mathrm{m}(\mathrm{A}), 20 \mu \mathrm{m}(\mathrm{B})$

\section{Discussion}

We found 6 epizoic taxa on the surface of Chordodes brasiliensis from El Tala River of Catamarca. The most abundant epibionts were diatoms and caddisfly pupae. Additional organisms such as the Elmidae larvae, Macrelmis spp. and Phanocerus spp. occurred in less proportion.

Caddisfly larvae and pupae are aquatic; they are sensitive to pollution and habitat degradation and are biological indicators of water quality (Merritt and Cummins1996). Also Phanocerus larvae are often good water quality indicators and have been used in several water quality experiments (Miserendino and Archangelsky 2006).

The abundance of epibionts found in C. brasiliensis could be explained on the basis of two aspects (1) environmental: El Tala River is not influenced by anthropic activity along its course, having an excellent water quality (Domínguez and Fernández 1998, Paez Zanini et al. 2006) and a great diversity of flora and fauna specially invertebrates (Salas 2003, 2005) and (2) characteristics of the basibiont: C. brasiliensis presents a very structured cuticular surface (De Villalobos et al. 2005) providing a better substrate for these epibionts.

A number of effects are related to epibiosis (Wahl and Mark 1999). These include advantages for the epibionts (diatoms, Trichoptera and Elmidae larvae) such as a suitable substratum, dispersal, access to light and nutrients. Also caddisfly larvae and Elmidae larvae have well developed mandibulate mouthparts which allow them to feed on diatoms and clean up the basibiont surface. Conversely, epibiosis may have the disadvantage of restricting the mobility of the basibiont (Chiavelli et al. 1993). Despite this, it is unlikely that diatom epibionts on gordiids surface were harmful. The short stature of the algal assemblage would have minimal physical effects, the diatoms apparently provided oxygen for the gordiids, which can be significant in low oxygen conditions, such as at the bottom of freshwater environments.

Caddisfly larvae can be found on the rocks, plants, mud or, as shown in this study, as epibionts of gordiids. Taking into account the existence of numerous studies that show a hostparasite association between Trichoptera larvae and the developing stages of various horsehair worms (White 1966 Cappuci 1976, Scari et al. 1986, Valvassori et al. 1988 , Schmidt-Rhaesa and Kristensen 2006), it is possible that the caddisfly larvae, as epibionts when moving along the body surface of gordiids could contact rocks or plants where a female had previously deposited eggs and feed from her developed eggs or larvae (eggs develop over 20-35 days see Hanelt and Janovy 1999; De Villalobos et al. 2003, 2006; Zanca et al. 2007; Achiorno et al. 2008, 2009).

Despite its wide occurrence, epibiosis is still not very well known with respect to its consequences for both basibionts and epibionts (Wahl and Mark 1999). Opportunism practiced by free-living trichopteran larvae, coleopteran larvae and diatoms should be investigated in future studies related to gordiids health problems.

Acknowledgements. We would like to thank two anonymous reviewers for constructive comments on the manuscript. Many thanks also to Patricia Sarmiento from the Scanning Electron Microscopy Service (Museo de Ciencias Naturales, La Plata, Argentina) for preparation of the material.

\section{References}

Achiorno C., De Villalobos C., Ferrari L. 2008. Effect of extreme temperature on egg development, larval and adult survival of Chordodes nobilii Camerano, 1901 (Gordiida, Nematomorpha). Acta Parasitologica, 53, 392-396. DOI: $10.2478 /$ s11686-006-0034-4.

Achiorno C., De Villalobos C., Ferrari L. (Eds.) 2009. Sensitivity of preparasitic stages of Chordodes nobilii (Gordiida, Nematomorpha) to malathion. Ecotoxicology, 18, 594-599. DOI: 10.1007/s10646-009-0317-2.

Begon M., Harper L., Townsend C. 1996. (Eds.). Ecology: Individuals, populations and communities. 3rd Edition, Blackwell Scientific Publications, Boston, $1068 \mathrm{pp}$. 
Cappucci D.T. 1976. The biology of Gordius robustus Leidy with a host list and summary of the public health importance of the Gordioidea. PhThesis. University of California, San Francisco, California.

Chiavelli D., Mills E., Threlkeld S. 1993. Host preference, seasonality, and community interactions of zooplankton epibionts. Limnology and Oceanography, 38, 514-583.

De Villalobos C., Rumi A., Núñez V., Schmidt-Rhaesa A., Zanca F. 2003. Paratenic hosts: larval survival strategy in Paragordius varius (Leidy, 1851) (Gordiida, Nematomorpha). Acta Parasitologica, 48, 98-102.

De Villalobos C., Zanca F., Schmidt-Rhaesa A. 2005. New data on South American species of Chordodes (Nematomorpha). Arquivos do Museu Nacional, Rio de Janeiro, 62, 375-386.

De Villalobos C., Ronderos M.M., Greco N., Zanca F., Díaz F., Achiorno C. 2006. Susceptibility of Aedes aegypti larvae to parasitism by Paragordius varius under laboratory conditions. Transactions of the American Entomology Society. 132, 121127.

Domínguez E., Fernández H. 1998. Calidad de los ríos de la cuenca del Salí (Tucumán, Argentina) medida por un índice biótico. Serie Conservación de la Naturaleza. Vol. 4. Fundación Miguel Lillo, Universidad Nacional de Tucumán, Argentina, $1-39$.

Hanelt B., Janovy J. 1999. Life Cycle of a Horsehair worm Gordius robustus (Nematomorpha: Gordioidea). Journal of Parasitology, 85, 139-141. DOI: 10.2307/3285720.

Hanelt B., Janovy J. 2004. Life cycle and paratenesis of American gordiids (Nematomorpha: Gordiida). Journal of Parasitology, 90, 240-244. DOI: 10.1645/GE-78R.

Hoagland K., Rosowski J., Gretz M., Roemaer S. 1993. Diatom extracellular polymeric substances: Function, fine structure, chemistry, and physiology. Journal of Phycology, 29. $537-$ 566. DOI: $10.1111 / \mathrm{j} .0022-3646.1993 .00537 . x$.

Kramer K., Lange Bertalot H. 1986a. "Bacillariophyceae: Naviculaceae". In: (Eds. A. Ettl, H. Gerloff, H. Heynig and D. Mollenhauer) Süßwasserflora von Mitteleuropa. Gustav Fisher Verlag, Stuttgart-New York, Vol. 2/1, 876 pp.

Kramer K., Lange-Bertalot H. 1986b. "Bacillariophyceae: Achnanthaceae. Kritische Ergänzungen zu Navicula (Lineolate) und Gomphonema". In: (Eds. A. Ettl, H. Gärtner, H. Gerloff, H Heynig and D. Mollenhauer) Süßwasserflora von Mitteleuropa. Gustav Fisher Verlag, Stuttgart-Jena. Vol. 2/4, 437 pp.

Manzo V. 2007. Cinco citas nuevas de Elmidae (Coleoptera) para la Argentina, con la redescripción de Austrolimnius (Telmatelmis) nyctelioides. Revista de la Sociedad de Entomologia Argentina, 66, 11-20.

Merritt R.W., Cummins K.W. (Eds.). 1996. An Introduction to the Aquatic Insects of North America. Publishing Kendall-Hunt Co., Dubuque, Iowa, $862 \mathrm{pp}$.

Miserendino M.L., Archangelsky M. 2006. Aquatic Coleoptera distribution and environmental relationships in a large Patagonian river. International Review of Hydrobiology, 91, 423-437. DOI: 10.1002/iroh.200510854.
Páez Zanini A., Ramos I., Vergara V., Veliz I., Rodriguez Garay G., Salas L. 2006. Diversidad de Insectos Acuáticos en el río El Tala. III Congreso Iberoamericano de Ambiente y Calidad de Vida, 24-27 Septiembre, 2006. Catamarca, Argentina. 119122.

Round F.E., Crawford R.M., Mann D.G. (Eds.). 1990. Diatoms. Biology and morphology of genera. Publishing Cambridge University Press, Cambridge, 747 pp.

Salas L. 2003. Biodiversidad de invertebrados bentónicos en el río El Tala (Catamarca). Congreso Regional de Ciencia y Tecnologia, 3-5 Julio, 2003, Catamarca, Argentina, 1-10.

Salas L. 2005. Biodiversity of mountain stream benthonic insects and their application to test the biological quality of the water. $X X I$ Annual Scientific Meeting, 21-23 October, 2005, Tafi del Valle, Tucumán, Argentina, 85.

Scari G., Di Lernia L., Magnetti P., Melone G., Valvassori R. 1986. Segnalazione di Gordius in Allogamus auricolis Pictet lungo un tratto del fiume Serio. Bollettino di Zoologia, 53, 60.

Schmidt-Rhaesa A. 2002. Australian species of Chordodes (Nematomorpha), with remarks on the genus and its life history. Journal of Natural History, 36, 1569-1588. DOI: 10.1080/00 222930110059664.

Schmidt-Rhaesa A., Biron D., Joly C., Thomas F. 2005. Host-parasite relations and seasonal occurrence of Paragordius tricuspidatus and Spinochordodes tellinii (Nematomorpha) in Southern France. Zoologischer Anzeiger, 244, 51-57. DOI: 10.1016/jcz200504002.

Schmidt-Rhaesa A., Kristensen P. 2006. Horsehair worms (Nematomorpha) from the Baltic Island Bornholm (Denmark), with notes on the biology of Gordius albopunctatus. Journal of Natural History, 40, 495-502. DOI: 10.1080/0022293060076 1803.

Trémouilles E., Oliva A., Bachmann A. 1995. Insecta, Coleoptera. In: (Eds. E.C. Lopretto and G. Tell) Ecosistemas de Aguas Continentales, Metodologías para su Estudio. Vol. 3. Ediciones Sur, La Plata, Argentina, 1133-1197.

Threlkeld S., Chiavelli A., Willey R. 1993. The organization of zooplankton epibiont communities. Trends in Ecology and Evolution, 8, 317-321.

Valvassori R., Scari G., De-Eguileor M., Lernia L.D., Magnetti P., Melone G. 1988. Gordius villoti (Nematomorpha) life cycle in relation with caddis fly larvae. Bollettino di Zoologia, 55 , 269-278.

Wahl M., Mark O. 1999. The predominantly facultative nature of epibiosis experimental and observational evidence. Marine Ecology Progress Series, 187, 59-66.

White D.A. 1966. A new host record for Paragordius varius (Nematomorpha). Transactions of the American Microscopical Society, 85, 579.

Zanca F., De Villalobos C., Rumi A. 2007. Larval survival strategy during winter of Chordodes nobilii Camerano, 1901 (Gordiida, Nematomorpha). Acta Parasitologica, 52, 382-385. DOI: $10.2478 / \mathrm{s} 11686-007-0055-7$. 